\title{
Like Father like Sons? The Cost of Sovereign Defaults In Reduced Credit to the Private Sector*
}

September 2015

\author{
Rui Esteves ${ }^{\#}$ and João Tovar Jalles ${ }^{+}$
}

\begin{abstract}
We investigate the impact of sovereign defaults on the ability of the corporate sector in emerging nations to finance itself abroad. We test the hypothesis that sovereign defaults have a negative spillover onto the private sector through credit rationing. We explore a novel dataset covering the majority of corporates in emerging nations that received foreign capital between 1880 and 1913. Results confirm that credit rationing existed, was very large, and persisted long beyond the default settlement. The private sector paid a severe cost for their governments' debt intolerance, with negative implications for the growth.
\end{abstract}

JEL: F32, F34, H63, N10, N20.

Keywords: Sovereign Default, Credit Rationing, Private Sector, Pre-1913.

\footnotetext{
* The authors are grateful to Milan Sojic for generously sharing data and to Sébastien Walker for research assistance. The paper has benefited from the comments and discussion of the participants in the 2012 conference of the Economic History Society, the workshop on Financial Crises and Workouts: Historical Perspectives (ANU, August 2012), and in seminars at the LSE, the Solvay Brussels School, ISEG and the Bank of Italy. Thanks also go to two anonymous referees for useful suggestions. The usual caveat applies and the opinions expressed herein are the authors' and do not necessarily reflect those of the OECD or its member countries.

\#Associate Professor of Economics, University of Oxford, Department of Economics, Manor Road Building, OX1 3UQ, Oxford, UK. email: rui.esteves@economics.ox.ac.uk.

${ }^{+}$Economist, OECD, Economics Department, 2, rue André Pascal - 75775 Paris Cedex 16 email: joao.jalles@oecd.org.
} 


\section{Introduction}

The fact that the source of the proverb 'Like father like son(s)' is lost in time attests to the pervasiveness of the assumption that children often inherit, through nature or nurture, their parent's manners and habits-usually the bad ones. Emerging nations usually 'emerge' into the international financial sphere by the hand of their governments. Sovereigns are often the first, and frequently the only, entities able to sell their bonds to foreign investors or to borrow from international banks. Later, private firms and municipals enter the international market to sell their own securities or attract FDI from foreign companies. In this sense, sovereigns are the parents in the story of this paper, while the private sector follows on as the children.

In this paper we investigate whether this common proverb was also currency among foreign investors, who considered applying their funds in emerging and developing nations. We start by quantifying the impact of sovereign defaults on the availability of foreign finance to the corporate sector in emerging nations. In our analysis, we allow for both price and credit rationing effects. The doctrine of 'sovereign ceiling', popular in the finance literature, is precisely predicated on the impact of defaults on the prices of private assets. According to this doctrine, private debtors cannot have a better credit than their sovereign, an assertion confirmed by some empirical evidence about the pricing of corporate bonds in emerging nations (Cavallo and Valenzuela 2010, Grandes et al. 2010). Other papers have tested for the direct impact of defaults or market measures of sovereign risk (spreads and ratings) on capital inflows to private corporations. These papers uniformly find a strong negative impact of sovereign risk (as measured by spreads) on lending to the corporate sector (Kaminsky and Schmukler 2002, Reinhart and Rogoff 2004, Das et al. 2010). Methodologically, our investigation is closest to the work of Arteta and Hale (2008) and Hale and Arteta (2009), who test for the contemporary and delayed effects of sovereign crises on the private sector's 
access to foreign credit and investment in a sample of emerging nations between 1984 and 2004.

We extend their analysis to the so-called first period of financial globalization by exploring a novel dataset covering the vast majority of corporates in emerging nations that received foreign capital between 1880 and 1913. Contrary to the prevalence today of 'NorthNorth' and 'upstream' capital flows, the world before 1914 conformed to the most basic predictions of the Solow neoclassical growth model for international capital flows. The bulk of these flows involved rich developed European countries exporting large surplus savings to capital-poor, but resource-rich nations and colonies all over the World. Not all this investment came to fruition, however. As today, credit booms were invariably followed by busts and painful deleveraging among net borrowers. The governments of some of these nations attempted to deleverage by force by defaulting on their external debts. Sovereign defaults, of course, are as old as sovereign debt, and creditors were not exactly caught by surprise nor were they impotent against bad debtors.

In the absence of an international bankruptcy law enforceable on sovereigns, creditors mobilized an array of enforcement mechanisms to reduce the outside, but especially the inside, option of a defaulter. Price rationing of defaulters is a well-established reaction, as default status and past repayment record figure prominently among the determinants of spreads in emerging economies both today (Eichengreen and Portes 1989, Eichengreen et al. 2001, Gelos et al. 2011, Kaminsky et al. 1998, Lindert and Morton 1989, Mody et al. 2001, Özler 1993) and in the period we cover in this paper (Flandreau and Zumer 2004, Mauro Sussman and Yafeh 2006). However, the literature has also shown that the impact on spreads tends to be short-lived or small after the settlement of defaults (Sandleris 2012).

A more extreme version of punishment, credit rationing (total market exclusion), during and after the default was more applied in the historical period than it seems to be today. Tomz 
(2007) documents how countries in bad standing were excluded from the market prior to 1914. On the contrary, there seems to be little evidence that the same applied to any country after the 1980s (Lindert and Morton 1989, Sturzenegger and Zettelmeyer 2006), although Cruces and Trebesch (2013) have recently questioned this consensus by showing that spreads and periods of market exclusion post-default are significantly correlated with the size of haircuts. Both in theory and in history, there is a presumption that these embargoes (and the widening of spreads) applied not only to the impecunious sovereign itself but also to the private sector. In doing so, the option value of defaulting was lowered even more for the tempted sovereign.

The literature has considered several mechanisms to justify a spillover effect from sovereign defaults to the access of the private sector to foreign funds. One interpretation, consistent with Bulow and Rogoff's (1989) model, sees this extension as part of the overall penalty imposed on the sovereign, that is naturally not indifferent to the condition of the economy (Rose and Spiegel 2002, Mitchener and Weidenmier 2010, Flores 2010). Alternatively, other authors trace the link between default and private credit to balance-sheet effects (Broner and Ventura 2010, Guembel and Sussman 2009) or interpret it as a reputational loss for the private sector that extended beyond the repeated game played between sovereign and foreign creditors (Cole and Kehoe 1998, Andrade 2009, Sandleris 2014). Forcing a bit our metaphor, in the first case children are punished to harass their parents, whereas in the second people infer that they had inherited the sins of their progenitors.

Unfortunately, from an empirical point of view, the predictions from these two literature strands are largely observationally equivalent. For instance, Sandleris's (2014) framework is orthogonal to the majority of the literature on sovereign debt because bondholders cannot sanction sovereigns and there are no reputational effects of a default. ${ }^{1}$ Despite this, 
sovereigns are still incentivized to repay in good states of the economy (rather than defaulting strategically), because they have private information about the state of the economy at the time they have to decide to repay the debt or default. In a bad state, it is less costly for society to default, but the default signals the bad state to private agents. Therefore, a default has two competing effects: entrepreneurs reduce their demand for funds (what the author calls an 'investment channel') and creditors reduce their willingness to lend ('credit channel'). Depending on which channel is stronger, the domestic cost of capital may rise or fall, but private agents will still be rationed out of funds, leading to an inefficiently low level of private investment after a default episode. The outcome of defaults is the same as in more standard models of default punishment, but for different reasons. The domestic corporate sector is not rationed out of credit as a consequence of the direct penalties against the sovereign (à la Bulow and Rogoff 1989), but because of the informational content of defaults about the economic fundamentals that drive returns in the private sector.

The remainder of the paper is organized as follows. In the next section we explain the nature and composition of the data, and describe the empirical methodology. The results of the main models and further robustness tests follow in section 3. Section 4 concludes.

\section{Data and Empirical Approach}

\subsection{Historical Data Set}

Our dataset comprises information on the status of sovereign debt, foreign capital flows to the corporate sector, as well as economic and political controls, and indicators of other types of financial disturbances (banking and currency crises) for a panel of 23 sovereign nations over 
the period 1880 to 1913 . Some of these nations changed status in our sample period, for instance Australia moved from a set of self-governing colonies to a sovereign Dominium with federation in 1901.

The control group contains sovereigns that never defaulted in the sample window as well as the defaulting countries outside of the actual defaults. The inclusion of the first group of countries aims to distinguish our mechanism from possible contagion effects stemming from defaults of neighboring sovereigns. That is to say, the control group in our regressions includes emerging nations with similar economic structures to the defaulters, so that the estimates represent country-specific penalties and not penalties by groups of nations, defined by geography, endowments or other observable characteristics. Therefore, our estimates should net out as much as possible contagion effects. In any case, the tenor of the results is not affected by restricting the sample exclusively to countries that defaulted. Because of missing data, the full usable set of observations is 734 . Table 1 lists the countries included, the period covered for each, as well as their status.

\section{Table 1 around here}

Table 1 also classifies countries into either emerging or developed nations. This classification will be used later mostly for practical purposes and it is not only based on a specific GDP threshold. ${ }^{2}$ The final column lists the periods under default in our sample, which represent a total of 66 country-years or 9 percent of the total panel. Compared with today, defaults in the historical sample were longer. The median length of defaults is 57 months, whilst the corresponding figure for Arteta and Hale's (2008) 1984-2004 study is 17 months.

Before describing the empirical methodology, it is interesting to get a first feel of the effect under scrutiny through a simple descriptive regression of private capital inflows against time 
indicators for defaults, as well as for three years before and three years after each default. ${ }^{3}$ The unconditional effect of defaults in this regression is quite large implying that domestic firms got $£ 2.8$ million less in foreign credit and investment during a default episode. ${ }^{4}$ Since the omitted categories are 'normal' years away from default episodes, there is also evidence of credit booms in advance of sovereign defaults. Private inflows are $£ 2.3$ million above normal three years prior to a default. ${ }^{5}$ Finally, the drop in capital inflows persists for at least three years ( $£ 1.5$ million below normal), although the post-default coefficients are statistically insignificant.

\subsection{Empirical Model}

The unconditional estimates are only suggestive since we have not yet controlled for other factors, which were likely to have reduced inflows around defaults. We do so by estimating the following panel model with fixed effects:

$$
\operatorname{priv}_{i t}=\alpha_{i}+\alpha_{t}+\beta_{0} d_{i t}^{S}+\beta_{1} n_{i t}+\beta_{2} r_{i t}+\gamma_{1} e^{-\theta_{1}\left(t-d_{i}^{S}\right)}+\gamma_{2} e^{-\theta_{2}\left(t-r_{i t}\right)}+X_{i t}^{\prime} \eta+\varepsilon_{i t}
$$

where $\operatorname{priv}_{i t}$ is a measure of credit to the corporate sector of country $i$ on year $t$, captured by the $\log$ of the flows of portfolio investment and FDI, originated in one of the three largest capital exporters, Great Britain, France or Germany (or the aggregation of the three, which will be referred to as "total flows"). The equation includes a set $\alpha_{i}$ of country fixed effects absorbing permanent time-invariant differences across nations, while $\alpha_{t}$ is a set of (year) time effects absorbing the effect of an underlying common trend. This specification allows separating the announcement, continuation and resolution impacts of a sovereign default. The first variable $d_{i t}^{S}$ is a dummy variable that takes the value 1 in the year the default started, $n_{i t}$ 
is an indicator of each year during which the country is in default and $r_{i t}$ is an indicator of a restructuring agreement year (corresponding to the last year in default).

We also control for the length of defaults $\left(t-d_{i t}^{S}\right)$. Despite the fact that the length of defaults was likely to depend on the current economic and political condition of the county (reflected in the vector of control variables $X_{i t}{ }^{\prime}$ ), we expect the coefficient $\gamma_{1}$ to capture the non-linear increase in the penalty imposed by foreign markets on the corporate sector of a defaulting nation - particularly in the cases of the longest defaults included in our sample, such as Colombia (1880-1896) and Peru (1876-1889). Alternatively, this variable may capture the costs of aggressive and non-cooperative debt policies by sovereigns, which increase the penalties from default to the corporate sector (Trebesch 2009). We model this effect as a decaying exponential function with parameter $\theta_{1} \cdot{ }^{6}$ Relative to baseline given by the default markers $n_{i t}$, this variable corrects the model's estimate of the impact of longer defaults. ${ }^{7}$ Since we expect shorter defaults to be less painful, we expect that $\gamma_{1}$ will have a positive sign.

We also introduce a memory variable to capture the residual rationing effect after the restructuring agreement. ${ }^{8}$ The coefficient $\gamma_{2}$ is therefore of central interest to our hypothesis about the long-term impact of defaults on the corporate sector. As in the case of the default length, we allow for an exponential decay of memory with parameter $\theta_{2} \cdot{ }^{9}$ The expected sign of $\gamma_{2}$ is negative. Finally, $\varepsilon_{i t}$ denotes a set of robust errors satisfying the standard assumptions of zero mean and constant variance.

As already mentioned, Arteta and Hale (2008) estimate a similar reduced-form model for the two last decades of the previous century. They find a 20 percent drop in access to foreign capital by corporates in emerging nations following a default episode. The paper that comes closer to testing the same effect for a historical period is Flores (2011), who uses data on British capital flows to foreign corporates. Flores (2011) finds no effect of defaults on foreign 
credit to private firms, but we show below that this result is not robust for two main reasons. First, the author did not use the information on French and German private investments, which raises a question about sample selection bias. Second, the author only tries to measure the contemporary effect of defaults, whereas we also quantify the delayed (or 'memory') impact after the onset of the default episode. To better compare our results with these two papers, we will measure the dependent variable priv $v_{i t}$ both as the aggregate foreign investment from the three main European capital exporters and from Britain only. The dependent variable was expressed in pounds sterling and converted into real terms by deflating the capital flows by the UK price level.

The set of control variables in vector $X_{i t}$ ' may affect the inflow of capital either through a contraction of supply (scarring of foreign investors), or by depressing the demand for finance by domestic firms while the economy (or the political situation) does not recover enough to warrant investment. Our intent in this paper is mainly to identify the scarring effect of supply, but the reduced-form approach of these regressions does not allow a clean identification, as we will discuss in section 3.2.

The control variables describe different dimensions of the economy, similarly to Arteta and Hale (2008). As many of the variables we would like to control for are highly correlated, we summarize them in indices using factor analysis from six identified blocks of variables.

We start by grouping the variables into six self-explanatory blocks, as described below, and summarized in Table 2. We then use Principal Component Analysis (hereafter PCA) to obtain the common factor(s) of each block of variables. The sources for each component variable are described in a Data Appendix available upon request and the resulting indices (principal components) are described in Table 2.

- International competitiveness:which influences firms' profitability and consequently their demand for credit. It also translates into the country's ability to generate enough foreign 
exchange to service its external debt and, therefore, affects foreign investors' interest in the country. We use the following variables to construct the index: an exogenous measure of the terms-of-trade, the trade account, total exports, total imports, and tariff levels. Only the first principal component was retained. ${ }^{10}$

- Investment climate and monetary stability should also affect the demand for investment and the country's level of attractiveness to foreign investors. The following variables were considered: debt service over government revenue (as a proxy for fiscal sustainability), total exports per capita and the inflation rate. Only the first principal component was used. ${ }^{11}$

- Financial development: which affects firms' domestic funding opportunities, hence their demand for foreign capital and their ability to service foreign debt, consistent with Sandleris's (2014) model of domestic credit rationing. In the absence of comprehensive data coverage for the usual measures of financial development, we only retained a dummy variable for gold standard membership. ${ }^{12}$ The logic here is that only countries with sufficiently developed financial systems were able to remain in the gold standard (Bordo and Flandreau 2003).

- Long-run macroeconomic prospects: which influence investment demand through the investor's assessment of a given country's growth prospects. We included the following variables: arable land, the economic distance from London, 5-year lag of net migration index, population growth, schooling level of population, and the urbanization rate. Two principal components were retained. ${ }^{13}$

- Political stability: unstable political environments may lead to a reduction in firms' investment and thus their demand for capital, as well as to foreign investors' concerns about their ability to recover their assets in the future. Several alternative definitions of conflict from the Correlates of War project were used, namely dummy indicators for 
extrastate war, interstate war, interstate disputes and internal war. Only the first principal component was used. ${ }^{14}$

- Global supply of capital: reflects the general availability of capital, changes in investors' risk perception and their willingness to provide credit to emerging economies. This index uses: the market rate for 3 months bills in London (a proxy for world short term interest rates) and the yields on British consols, as benchmark for long-term world interest rates. Both were retained in the regressions. ${ }^{15}$

In addition to these indices, we explicitly include the real exchange rate among the covariates, as a control for the size of macroeconomic imbalances. To account for the effects of extra financial volatility we also included markers for years with banking crises and currency crises. All variables are transformed in logarithms except those which are shares, rates, or binary dummies. To allay endogeneity concerns, all variables are lagged by one year (with the exception of global supply of capital measures). ${ }^{16}$

\section{Table 2 around here}

Given that PCA is based on the classical covariance matrix, which is sensitive to outliers, we take a preliminary step by basing it on a robust estimation of the covariance (correlation) matrix. A well suited method is the Minimum Covariance Determinant (MCD) that considers all subsets containing $\mathrm{h} \%$ of the observations and estimates the variance of the mean on the data of the subset associated with the smallest covariance matrix determinant - we implement Rousseeuw and Van Driessen's (1999) algorithm. After re-computing the same indices with the MCD version we obtain, generally speaking, similar results, meaning that outliers are not driving our factor analysis. ${ }^{17}$ 
Furthermore, the sampling technique is unfortunately restricted by the fact that cross country coverage is not complete and varies across different data sources. This limitation creates an incomplete data issue and poses a problem for PCA. ${ }^{18}$ Hence, imputation may be required prior to extracting the first principal component. ${ }^{19}$ We used the ExpectationMaximization Algorithm (EMA), as suggested by Dempster et al. (1977) to fill a relatively small share of missing data. This algorithm is based on iterating the process of regression imputation and maximum likelihood and it consists of two steps: the first step, the "E (expectation)-step" computes expected values (conditional on the observed data) and the current estimates of the parameters. Using the estimated "complete data", in the second step or "M-step", the EMA re-estimates the means, variances and covariances using a formula that compensates for the lack of residual variation in the imputed values. ${ }^{20}$ Overall, we had to impute a very small number of observations. ${ }^{21}$

As recorded in Table 2, we retained just one principal component in three out of four blocks of variables. Table 3 lists the corresponding factor loadings.

\section{Table 3 around here}

We can interpret the principal components by focusing on the factor loadings onto them and the uniqueness of each variable. ${ }^{22}$ Given the high uniqueness of terms-of-trade and tariff levels, the international competitiveness factor essentially describes the actual openness to trade (exports and imports) of each economy. Hence, we expect a positive sign of this factor in the regressions. Although none of the investment climate variables is well explained by the factor analysis, this factor is driven by two risks associated with sovereign, but not necessarily private securities: the risk of default and the risk of inflation. As foreigners had the choice of investing in sovereign bonds or in private securities, this factor could enter the 
regressions with a positive or negative sign. If, on the one hand, foreign investors invested in private assets as a hedge against inflation and default risk then the sign would be positive. If, on the other hand, private assets were not good hedges we would expect this factor to reduce private capital inflows. ${ }^{23}$

All the war variables have high uniqueness, all have positive factor loadings, and hence we expect the corresponding principal component to enter negatively in the regressions. ${ }^{24}$ Finally, long-turn macro fundamentals are represented by two factors. Uniqueness is low for most variables (except for the availability of arable land and schooling levels), which implies that the two factors retained span the original variables adequately. ${ }^{25}$ As is evident from Table 3, the second factor mostly reflects urbanization and the schooling level of the population, whilst the first factor appears to describe the endowment structure of the comparative advantage of most emerging nations in the period (population growth and immigration, plus natural resources), as well as the trade costs, measured by the economic distance from Europe. In principle, both factors could enter with positive coefficients in the regressions, although it is possible that the second factor, which is orthogonal by construction to the first, captures the growth of the non-traded sector. ${ }^{26}$ In this sense, a negative sign of the coefficient for the second factor would be consistent with an interpretation where excessive growth of the non-traded sector would lead to real exchange rate appreciation, and possibly to current account imbalances that scared foreign capital away.

We now move to describe the empirical results in the next section, where we estimate equation (1) by fixed effects panel and Generalized Method of Moments (GMM).

\section{Empirical Results}




\subsection{Fixed Effects Panels}

In this section we present the results of the estimation of equation (1) using fixed effects panel methods. This is a reduced-form exercise aimed at quantifying the total contraction of capital inflows to the private sector during and after sovereign defaults. Although they do not directly address endogeneity, these estimates provide a benchmark to compare with similar reduced-form exercises such as those by Arteta and Hale (2008) and Flores (2011). In particular, to compare with the results of the latter we re-estimate equation (1) using only information on British capital flows in the left-hand side.

Table 4 collects the estimation results. The impact of sovereign defaults is quite marked, although decreasing in the years when a rescheduling agreement is reached. Before commenting on these results it is important to remember the interpretation of the coefficients of the first five variables. As the left-hand variable is measured in logs, the first three dummies should be interpreted as the proportional decrease in the explained variable. For instance, the coefficient for the default year in column (1) -0.96 implies a drop in private capital inflows of the order of 62 percent (relative to the non-default counterfactual), even though it is not statistically significant in this specification. Moreover, the estimates of these dummies have to be interpreted in conjunction with the exponential measures of length of defaults and memory of past defaults. For instance, the estimate of the impact of a default lasting $t$ years is given by $\exp \left\{\hat{\beta}_{1}+\hat{\gamma}_{1} e^{-\theta_{1} t}\right\}-1$, which corresponds to the percentage change in capital inflows relative to the non-default case after $t$ years in default. Consistent with our expectation, in this specification there is weak evidence that longer defaults attracted progressively higher penalties, as the coefficient on the exponential decay for default length $\left(\gamma_{1}\right)$ is positive.

Moving on to the results controlling for all covariates (column 2), the size of the coefficients on the variables of interest falls uniformly. This was to be expected, as countries 
often defaulted under the weight of difficult economic conditions, which also affected the corporate sector. Even though we will deal with this source of endogeneity more thoroughly in the next section, the comparison between the estimates of columns (1) and (2) provides a lower bound to the endogenous response of capital inflows and sovereign finance to economic conditions in the recipient nations. In particular, the coefficient for years in default is now $30 \%$ smaller than the equivalent effect in column (1). Likewise, the estimate of $\gamma_{1}$ is larger in column (2), which implies a stronger effect of the length of defaults. In fact, the estimate of $\gamma_{1}$ is so large that it more than compensates the negative impact of the baseline dummy markers. Once we introduce the control variables, the direct effect of the default is much smaller and inflows to the private sector would not have fallen immediately. In this model it takes two years in default before the private sector starts losing in net terms. We refer to this as a portfolio recomposition effect, whereby foreign investors could reduce their exposure to the sovereign sector by investing the proceeds in the corporate sector of the defaulting nation. Durbin and Ng (2005) documented cases of violation of the 'sovereign ceiling' rule for corporate debt trading at lower yields than the respective sovereign, especially for firms in the traded sector with access to foreign exchange through large export earnings or an affiliation with a foreign company. ${ }^{27}$

These results suggest that a substantial part of the credit rationing to the private sector is explained by the controls, but that there is still a large fraction unaccounted for, either driven by unobservables or by the endogeneity of some of the right-hand-side variables.

\section{Table 4 around here}

The memory effect after a default had been rescheduled is negative, statistically significant and of similar size in both models. In column (2) it starts at $-56 \%$ in the first year after 
settlement, it then drops to $-39 \%$ after 5 years and $-25 \%$ after 10 years. This is not only a very persistent effect, but also a large one, which underscores our interest in the lingering effects of past defaults on the corporate sector long-term capacity to attract foreign finance.

The estimates of the control variables (column 2) suggest a greater relevance of domestic covariates compared to external sources of variation. Among the domestic covariates, gold standard membership and the first factor of long-term macro fundamentals have a strong and statistically significant positive impact on private capital inflows. The latter, as argued previously, is related to the comparative advantage of most emerging economies in this period. ${ }^{28}$ The second factor of macro fundamentals is much weaker as a predictor of capital inflows. The indicators of international competitiveness, monetary stability and investment climate, political instability and world liquidity are not statistically significant. These negative results are perhaps less surprising then at first sight. On the one hand, wars, monetary and fiscal instability and loss of competitiveness were the most common causes of defaults, so that the effect of the former might already be captured in the default dummy itself. The low frequency of annual data might be another reason why we cannot identify a clear impact of these variables.

On the other hand, the irrelevance of British interest rates as proxies for world liquidity and risk appetite is probably just an expression of the environment of exceptionally low returns at the European core and which partly explained the great waves of capital export from Europe to emerging nations around the World prior to the Great War (Mauro, Sussman and Yafeh 2006). ${ }^{29}$ The gold standard variable has a positive and very large coefficient, implying an increase in capital inflows by close to $115 \%$ relative to countries outside the standard. Despite Catão and Solomou's (2005) evidence of large real exchange rate variations in the classical gold standard period, this variable is usually insignificant in our models. Finally, the time dummies identifying currency or banking crises add very little explanatory 
power, which reinforces our confidence that our model adequately captures the essence of the foreign investors' decision model.

Column (3) in Table 4 estimates the model exclusively for British capital outflows. The overall fit is worse than for the full sample and, in particular, the default markers are now all statistically insignificant. Although this might be partly due to the smaller sample size, it confirms our suspicion that the negative result in Flores (2011) was driven by sample selection, namely by not including data on French and German capital exports. A possible interpretation of this result is the smaller exposure of the British portfolio to emerging sovereigns, compared to French and German foreign investments (Stone 1999, Esteves 2011). This would then lead to an under-representation of episodes of sovereign distress in a sample of British capital exports.

\subsection{Endogeneity}

\subsubsection{System GMM Estimation}

The models described in the previous sub-section are all reduced-form and therefore do not allow making causal statements or even quantifying the clean effect of defaults on capital inflows. Adding covariates partly corrects for these biases, but endogeneity can still arise from other omitted variables (unobserved heterogeneity and selection effects), measurement errors in variables, and reverse causality (simultaneity). Because causality can run in both directions, some of the right-hand-side regressors may be correlated with the error term. For instance, standard theories of sovereign debt predict that countries default when faced with a bad shock to their ability to pay. ${ }^{30}$ This carries the practical implication for our estimations that lagged economic and political fundamentals might have determined both defaults and stops of external finance to the private sector. There is also scope for reverse causation, as 
external shocks to the country-specific availability of finance (not captured by the measures of world interest rates) might have forced a default through a deterioration of economic activity in small open economies. ${ }^{31}$ Preliminary investigation revealed that the dependent variable was serially correlated such that we are required to use a dynamic panel approach to get consistent estimates of equation (1).

Because the first-differenced GMM estimator can behave poorly if time series are persistent, we use the more efficient system GMM estimator that exploits stationarity restrictions. This method jointly estimates equation (1) in first differences, using as instruments lagged levels of the dependent and independent variables, and in levels, using as instruments the first differences of the regressors (Arellano and Bover 1995, Blundell and Bond 1998). ${ }^{32}$ Similarly to all instrumental variable methods, GMM estimators are unbiased, and compared with OLS or fixed-effects (within-group) estimators, exhibit the smallest bias and variance (Arellano and Bond, 1991). The results of this estimation are collected in the first two columns of Table 5.

\section{Table 5 around here}

Compared to the fixed-effects estimates, the set of results in Table 5 column 1 imply a stronger penalty from default passed on to the private sector. Even though there is a recomposition effect for short defaults (inflows increase by an estimated 39\% in defaults of up to a year), the penalty is very severe from then onwards. After four years in default, capital inflows fall by $23 \%$ and this contraction grows slowly to $-71 \%$ after 5 years - the median length of defaults in our historical sample. The memory effect after the settlement of defaults is also stronger in this model than in Table 4. The pattern of covariates is similar to that in Table 4, although the international competitiveness factor is now statistically significant. 
Both indices of macro fundamentals are statistically significant in this specification, albeit with smaller point estimates. Although we will return to this issue in the next section, the fact that the second macro fundamental enters positively seems to dispel the hypothesis that an excessive growth of the non-traded sector could lead to crises and penalize access to foreign finance by emerging nations. Interestingly, the marker for the gold standard is no longer significant, which supports the literature on the 'thin film' of gold that underscores the endogenous nature of monetary regimes (Flandreau and Zumer 2004, Ferguson and Schularick 2012). Column 2 repeats the estimation for British capital flows only and confirms the selection effect already found in Table 4 and commented above.

\subsubsection{Structural Estimates}

Even though the results in Table 5 underscore the presence of endogeneity, they offer no clear idea about the source of the drop in access to foreign finance by domestic corporate. This could be driven by a reduction in supply by foreign investors or a drop in demand by the corporate themselves, in response to the depressed investment opportunities during the default and, perhaps for some time after as well. To try and quantify this directly, we estimate by 3 SLS the following system with a demand and a supply equation:

$$
\begin{aligned}
& \quad s_{i t}=\alpha_{i}^{s}+\alpha_{t}^{s}+\beta_{0}^{s} d_{i t}^{s}+\beta_{1}^{s} n_{i t}+\beta_{2}^{s} r_{i t}+\gamma_{1}^{s} e^{-\theta_{1}\left(t-d_{i}^{s}\right)}+\gamma_{2}^{s} e^{-\theta_{2}\left(t-r_{i t}\right)}+X_{i t}^{d \prime} \eta^{s}+ \\
& X_{i t}^{s \prime} \varphi^{s}+\varepsilon_{i t}^{s} \\
& \quad \operatorname{priv}_{i t}=\alpha_{i}^{d}+\alpha_{t}^{d}+\lambda s_{i t}+\beta_{0}^{d} d_{i t}^{s}+\beta_{1}^{d} n_{i t}+\beta_{2}^{d} r_{i t}+\gamma_{1}^{d} e^{-\theta_{1}\left(t-d_{i}^{s}\right)}+\gamma_{2}^{d} e^{-\theta_{2}\left(t-r_{i t}\right)}+ \\
& X_{i t}^{d \prime} \eta^{d}+\varepsilon_{i t}^{d}
\end{aligned}
$$

The first equation is the supply function that determines the country-specific cost of credit $s_{i t}$, defined by the spread of the country's sovereign bonds against the British long-term 
benchmark (consols), from the same covariates of equation (1). ${ }^{33}$ As we do not include $p r i v_{i t}$ in the supply function, this formulation implies a perfectly elastic supply schedule, which despite being a strong assumption it is justified by the fact that most countries in the sample were small open economies and price takers in the international capital market. Moreover, there is evidence that the increasing competition in international capital markets compressed spreads in the decades prior to World War I (Mauro, Sussman and Yafeh 2006). This cost of credit enters as an additional explanatory variable in the demand equation (3). The identification rests on the exclusion of the block of covariates $X_{i t}^{S \prime}$ from the demand equation. To operationalize this system we include in $X_{i t}^{s}$ the two proxies for the global supply of capital, i.e., the short and long-term British interest rates. By including $X_{i t}^{d \prime}$ in both equations, we can separate the effect of each of the covariates through demand contraction (what Sandleris 2014 refers to as the 'investment channel') and credit constraint ('credit channel').

Ideally, we would measure $s_{i t}$ with country-specific series of private cost of capital, as Hale and Arteta (2009) did for their study of the impact of currency crises between 1984 and 2004. Despite the existence of aggregate indices of returns on private foreign investments for this period for all capital exporters, we are not aware of similar series disaggregated by recipient countries. ${ }^{34} \mathrm{We}$ were therefore forced to proxy sit with the spreads on the sovereign bonds of the corresponding country. This rests on a somewhat loose application of the 'sovereign ceiling' rule. Even though it is usually verified, this principle ignores possible variations in the size of spreads between corporates and sovereigns. As this is more likely to happen around a default, by using sovereign spreads we are probably overstating the impact of supply shocks through the estimate of $\lambda$. However, the data requirements necessary to build a panel of corporate spreads are insurmountable at this time, and so we are left with the single choice of using sovereign spreads as proxy. ${ }^{35}$ 
The last two columns in Table 5 report the 3SLS estimates of the system of equations (2)(3). Since the dependent variable in equation (3) is the country bond spread, this equation is estimated as an inverse supply function. ${ }^{36}$ Results show that supply shocks dominated demand retraction for foreign finance in the wake of a default episode. As expected, defaults had a severe impact on the cost of sovereign borrowing (column 4), increasing spreads by over 300 basis points on the first year. In longer default cases, spreads rose even further by close to 700 basis points and remained this high until the rescheduling agreement. The markers of default are less significant in the demand equation (column 3), but the recomposition effect, found in previous models, is also present and significant and for short defaults (up to a year). Interestingly, there is evidence of a complementary effect on the supply equation, as the negative coefficient on the length of defaults implies that the spread penalty increased with longer defaults.

Still consistent with previous findings, there is a lingering effect of defaults on corporates' demand for foreign finance after the default had been settled, as well as a persistent penalty on spreads, starting at circa 150 basis points in the year after settlement and falling down to 40 after ten years. These estimates are similar to Flandreau and Zumer's (2004) finding of a 90 basis points penalty one year after settlement, subsequently halved after ten years. There is, therefore, evidence of demand and supply factors in explaining the observed contraction of borrowing in accordance with the hypothesis of this paper about credit rationing to the private sector, as a consequence of sovereign risk. Nevertheless, the stronger fit and size of the coefficients on the supply equation suggest that the reaction of supply dominated that of demand in the wake of defaults.

The estimates of the controls are now more significant than in the single equation models and have the expected signs. By construction, all the factors are re-scaled to have zero mean and unit standard deviation. Consequently, we can compare the economic significance of 
each factor from the relative size of their coefficient estimates. ${ }^{37}$ By this metric, international competitiveness dominates in the demand equation, followed by macro fundamentals. Both macro fundamentals are statistically significant and positive, but the first is larger than the second. This partly accords with the intuition that the second factor is driven by the growth of the non-traded sector, which attracted less foreign capital than the exporting sector of emerging nations in the nineteenth century. This is also confirmed by the fact that the second component has a positive and statistically significant impact on spreads, unlike the first. The order of economic significance is similar in the equation for spreads (column 4). Contrary to the 'thin film of gold' literature, even though the gold standard membership variable is statistically insignificant in the demand equation, it still reduces spreads by 74 basis points in the supply function.

British interest rates have an impact on sovereign spreads (as expected) but with a negative sign. A negative relationship between benchmark yields and spreads has also been found elsewhere and there have been some attempts at explaining it. Eichengreen and Mody (2000) interpret this result as an expression of adverse selection. During periods of high benchmark yields, good borrowers withdraw from the market temporarily, while low quality borrowers remain willing to pay more. For the first group of borrowers, the relation would be negative while it would be positive for the second. The negative coefficient we found therefore implies that the bulk of international capital exports in this period was absorbed by 'good borrowers,' a fact consistent with the evidence on the good ex post returns of these investments (Edelstein 1982, Eichengreen and Werley 1988, Esteves 2011, Lindert and Morton 1989, Schaefer 1993). Uribe and Yue (2006) provide a model of overshooting where spreads increase on impact with a rise of the benchmark yield, decrease afterwards, and remain permanently above the initial level thereafter. Given the low frequency of our data, the negative coefficient that we found may be capturing this intermediate decrease in spreads 
after the overshooting. Another notable result is the statistical insignificance of the spread variable in the demand equation, which raises questions about the suitability of sovereign spreads as proxies of borrowing costs of the private sector during a default episode. As we will see in the next section, this may be also driven by a composition effect of different economic sectors and, consequently, we defer further comment until then.

\subsection{Interpretation}

Despite the differences found between the results of Tables 4 and 5 , the estimates of the impact of defaults on capital inflows to the corporate sector are remarkably stable and consistent across models. To establish this, we use the point estimates of the default markers to plot the time path of capital flows after a default episode in Figure 1. The point estimates are plotted as percentage deviations of capital inflows relative to the non-default baseline and respect the non-linear structure of equation (1).

\section{Figure 1 around here}

To be consistent with the median length of defaults in our sample (57 months), Figure 1 represents the case of a default episode lasting 5 years. The estimates from Table 4, column 1 (labeled FEs in Figure 1) imply a sharp and increasing reduction in inflows reaching a minimum of only $25 \%$ of normal levels in the year of the settlement. Thereafter the corporate sector recovers access to foreign finance slowly and it is still $40 \%$ below normal levels 5 years after the end of the episode. Compared with this, the GMM estimates (Table 5, column 1) show a smaller initial penalty, even a possible gain in the first two years, consistent with a portfolio recomposition away from sovereign bonds and in favor of private assets. Nevertheless, longer defaults eventually converge to a net loss, which is of the same 
magnitude of the FEs results by settlement time. After the settlement, GMM results point out to a slower recovery, such that flows are close to $50 \%$ below normal after 5 years. Finally, we also represent in Figure 1 the time series of demand for foreign capital (Table 5, column 3), which starts by rising but then falls faster than the other two estimates during the default and also recovers faster afterwards.

Such differences between estimates are not difficult to interpret. First of all, the endogeneity of the decision to default was likely to bias up the estimates of the impact during defaults; once we control for the endogenous state of the economy, the 'pure' effect of the default itself is reduced. A similar reasoning explains why the fixed effects results overestimate the recovery of foreign inflows after the settlement of the default. The fact that demand for foreign finance initially increases is an interesting result, suggesting that the 'credit channel' dominates the 'investment channel' in short defaults, underscoring the rationing of the corporate sector by foreign investors. More prolonged cases of default episodes however, depress the demand for external finance to levels below the market equilibrium. Once more, the estimates of the drop in demand are similar to the total effect estimated by GMM by the time of restructuring and afterwards.

But notwithstanding these nuances, the estimates of all the models are within the confidence interval of the GMM model, which endorses the conclusions of this study. ${ }^{38}$ Arteta and Hale (2008) using a model similar to that of Table 4, estimated a $20 \%$ drop in foreign credit persistent up to two years in default. Consistent with our results, they find that this effect is not statistically significant during the default episode itself, but becomes significant after a settlement has been reached. Unlike our results, this penalty increases to $30 \%$ in the first year after settlement and remains at $20 \%$ three years after the debt agreement. The larger drops in capital flows estimated in our sample are certainly a consequence of historical defaults being longer than contemporary ones. Recall that the median length of 
defaults in the historical sample is 57 months, against 17 in Arteta and Hale (2008). However, if we compare the size of the fixed effects estimates at similar periods they are surprisingly close. In the historical sample, four years into a default episode, capital flows are cut by approximately $20 \%$ in the GMM estimates, a fact consistent with the scale of the penalty for the median length of default in Arteta and Hale (2008).

\subsection{Robustness}

We submit our models to three robustness exercises. The first investigates whether our reduced-form results are dependent on model selection. Secondly, we expand this to consider the stability of the coefficients of interest in the GMM models to the choice of control variables, instruments sets and lags. Finally, we investigate how different sectors in the economy reacted to sovereign defaults and whether the overall results are masked by composition effects.

\subsubsection{Model Selection}

It is well known that the inclusion of particular control variable in a regression can wipe out (or change the signs of) any given bivariate relationship (Easterly and Rebelo 1993). With these considerations in mind, we follow Leamer's (1983) extreme bounds analysis (hereafter EBA) and Levine and Renelt's (1992) empirical application of this model selection test. Adapted to our context, this implies the estimation of regressions of the form:

$$
Y=a_{j}+b_{y j} y+b_{z j} z+b_{x j} x_{j}+\varepsilon,
$$

where $y$ is a vector of fixed variables that always appear in the regressions (real exchange rate and banking crises), $z$ denotes the variable of interest (sovereign default), and $x_{j}$ is a vector of three variables taken from the pool of $X$ control variables. The regression model has to be estimated for the $M$ possible combinations of $x_{j} \in X$. If the lower extreme bound is negative 
and the upper extreme bound is positive, the variable is considered not to be robust. Vector $X$ is composed of all the variables presented in Table 2. This means we have 21 switch variables implying $C_{3}^{21}=1330$ possible combinations of $x_{j} \in X$. Table 6 presents our EBA results for the impact of defaults using both the aggregated total capital flows as British flows only (we just report the lower and upper bounds).

\section{Table 6 and Figure 2 around here}

We confirm the negative impact (statistically significant at usual levels) of sovereign defaults on the total level of real capital flows. Notice that this result is not robust for British capital flows; once again this is in line with Flores's (2011) results. Another consideration is whether the size of the sovereign default coefficient is influenced by the inclusion of specific conditioning variables. In order to test this, we have computed the conditional mean effect size of a sovereign default, i.e., the mean effect size conditional on the inclusion of a specific variable of the set of 21 switch variables that were previously selected. Figure 2 graphically illustrates the results.

The vertical bars in Figure 1 represent the 90\% confidence bands around the average (conditional) estimated default coefficient (indicated by the bold squares). The 21 conditioning variables indicated on the horizontal axis are organized as they were included in the EBA exercise. The conditional mean effect size ranges from -2.1 in the case of Terms of Trade to -1.6 in the case of total exports. However, Figure 2 also shows that most confidence intervals overlap, suggesting no statistically significant effect of the choice of conditioning variables on the size of the relationship between default and total level of real capital flows.

Alternatively, we employ the Bayesian Model Averaging (hereafter BMA). Essentially, BMA treats parameters and models as random variables and attempts to summarize the 
uncertainty about the model in terms of a probability distribution over the space of possible models. The method is used to average out the posterior distribution for the parameters under all possible models, where the weights are the posterior model probabilities. To evaluate the posterior model probability BMA uses the Bayesian Information Criteria (BIC) to approximate the Bayes factors that are needed to compute the posterior model probability, as discussed in more detail in Raftery (1995), Sala-i-Martin et al. (2004) and Malik and Temple (2009). The output of the BMA analysis includes the posterior inclusion probabilities for variables and a sign certainty index. ${ }^{39}$ The higher the posterior probability for a particular variable the more robust that determinant for external capital flows appears to be.

Table 7 summarizes the evidence by listing the models with highest R-squares for the dependent variable, both for the total capital flows and for British capital exports only. There is now mixed evidence on the inclusion of some of the original variables in the final model, even though the previous EBA results suggest that their exclusion should not affect the size of the coefficient of interest. This is another reason why we decided to apply a factor analysis to the six blocks of variables described earlier, as opposed to using the original individual variables.

\section{Table 7 around here}

\subsubsection{GMM Stability}

We now investigate whether the coefficients of interest vary in size, sign and significance with the inclusion of particular covariates in the equations estimated by system-GMM. To do so, we dropped non-significant covariates one at a time. All in all, we believe it is preferable to keep insignificant variables in to avoid any possible omitted variable bias, but if the covariates in question do not add information, then their exclusion should not affect the 
coefficients of the remaining variables. This is exactly what we found when we reestimated equation (1) by system-GMM dropping sequentially each of the insignificant covariates. ${ }^{40}$

Our final exercise checks whether the GMM estimates are sensitive to the choice of lags or the choice of instruments. It is well-known that an advantage of system-GMM is that it generates more internally available instruments. However, that is only one side of the coin, since it can also generate "too many instruments," in the sense that some may be "weak" leading to inefficient estimates (Roodman 2009). To test these two issues, we ran the GMM models with shorter lags (one year, instead of two) and with a shorter set of instruments. ${ }^{41}$ Here too, the point estimates of the coefficients were not statistically different from the results in Table 5.

\subsubsection{Sectorial Estimates}

In this section, we decompose foreign capital inflows into the exporting and non-exporting sectors of recipient nations. Some papers show that domestic firms can partly evade the strictures of a capital embargo by earning foreign exchange in the export market or, if they are owned by foreign companies, via internal financing (Blalock et al. 2008, Kalemli-Ozcan et al. 2010). Since we do not have detailed information on the trade account of the nations included in our sample, we use a blunt division between these two sectors, based on the stylized facts of international trade before World War I. Emerging nations in this period mostly exported primary commodities against the import of manufactured goods and services (O'Rourke and Williamson 1999, Williamson 2006). Consequently, we identified as exportables the agricultural and raw materials sectors for emerging nations, whilst we expanded this definition to include the financial and the industrial and miscellaneous sectors for the developed economies (as classified in Table 1). The non-exporting sector is composed of the transportation sector (namely railways), public utilities, and the financial sector in 
emerging economies. For concision, we only report in Table 8 the results of the 3SLS estimation of the system of equations (2)-(3). ${ }^{42}$

\section{Table 8 around here}

Breaking the sample by sectors yields some interesting insights. The demand for foreign finance of the exporting sector is significantly affected during a default episode, despite a large increase in spreads both during and after the default (Table 8, columns 1-2). Consequently, demand contraction and supply rationing combined in cutting external funding of the exporting sector. In the case of the non-exporting sector, the combination of default markers and the estimate of $\gamma_{1}$ imply that a default episode actually raises the demand for external funding (column 3), even though the point estimates are not statistically significant at conventional levels. A default also leads to a persistent increase in spreads, which is statistically significant throughout and larger than for the exporting sector (column 4). It appears as though credit rationing is the only driver of the contraction of external funding to the non-exporting sector. Arteta and Hale (2008) also found that only the firms in the nonexporting sector suffered a decline in foreign credit during default episodes. Since the bulk of the non-exporting sector in our sample is comprised of railways and public utilities, which were directly or indirectly supported by local governments, it is not surprising that their demand for outside finance should increase at the time when their usual source of credit was not available. This is also consistent with the fact that sovereign spreads seem to be a better measure of the effective cost of capital to this sector. Indeed, the demand curve (column 3) is now downward sloping, which combined with large and persistent impacts of default episodes on spreads, led to severe credit rationing. Finally, notice that the marker for banking crises is now statistically significant (contrary to Tables 4 and 5) in column (3) only, which 
suggests further the greater dependence of the non-exporting sector from domestic sources of funding. The pattern of results for the other covariates is broadly in line with those of Table 5.

The results of these structural models not only confirm the hypothesis of this paper, but unveil significant differences in the way different sectors in the economy reacted to defaultrelated credit constraints in international capital markets. Further research is desirable to identify with greater detail these effects, by using a finer, i.e., more disaggregated, classification of economic sectors.

\section{Conclusions}

In this paper we documented the consequences of sovereign defaults to the private sector between 1880 and 1913. This was a period of almost unrivalled worldwide financial integration, parallel only to our own wave of financial globalization since the late 1970s. In both periods, governments were the initial movers in taping the pool of international finance, followed by the private sector. In many countries this capital account opening led and continues to lead to financial crises that are associated with significant costs to the 'real economy.' In a recent synthesis, Reinhart and Rogoff (2009) used historical evidence to quantify these costs in terms of lost output, increased unemployment, and drop in the value of banking assets and household wealth. A related and vexed question is the impact of financial crises on the growth rate of countries exposed to international integration. Out of the many hypotheses advanced in the literature to explain this negative growth link, we singled out the rationing of external finance to domestic firms after default episodes. The identification of persistent rationing of investment projects by the private sector of emerging nations is an obvious candidate for a lower growth rate. 
We tested this hypothesis in a panel of emerging nations of the late $19^{\text {th }}$ and early $20^{\text {th }}$ centuries, and which imported the vast majority of all capital exported from Europe during the same period. Our results confirm that rationing was prevalent and very important not only during the actual period of default but especially after the renegotiation of debt was concluded and sovereigns tried re-financing themselves (many of them successfully) in international capital markets. In all models estimated, capital inflows to the private sector fell quickly after an initial period of portfolio recomposition away from sovereign securities. Accounting for endogeneity, we estimate a reduction of capital inflows by more than $70 \%$ five years after the default, which was then slowly reverted after settlement. Ten years after a default episode, we still estimate a $40 \%$ reduction relative to normal levels. These are larger estimates than those found by Arteta and Hale (2008) for a similar group of nations between 1984 and 2004 owing to the longer defaults in the historical sample covered in this study. When we compare the estimates at the median length of defaults in the two samples they are remarkably similar, namely a $20 \%$ drop in foreign inflows. In the two periods, the estimated rationing is particularly significant (in statistical terms) after the defaults had been settled, suggesting that a large share of the burden of financial retrenchment was borne over the longrun by the corporate sectors of these economies.

We further verified that the estimated drop in access to foreign finance was not exclusively due to lower demand for finance by private firms, perhaps because of the depressed domestic conditions which had led to the default in the first place. On the contrary, after controlling for possible sources of endogeneity, we identified a negative supply shock forcing credit rationing to the domestic corporate sector. This effect was particularly present in the case of borrowing from abroad by the non-exporting sector in emerging economies, whereas the exporting sector was less affected by the same shock. Our results confirm similar evidence found for the contemporary period, and underscore an apparent permanent source of 
financial disadvantage for firms in emerging nations, at least until the domestic financial system is sufficiently developed to provide for its own funding needs as well and those of the non-financial sector. 


\section{References}

1. Andrade, S. (2009) "A model of asset pricing under country risk," Journal of International Money and Finance 28(4): 671-695.

2. Arellano, M. and S. Bond. (1991) "Some tests of specification for panel data: Monte Carlo evidence and an application to employment equations," Review of Economic Studies, 58(2): 277-297.

3. Arellano, M. and O. Bover (1995) "Another look at the instrumental variable estimation error component models," Journal of Econometrics, 68(10): 29-51.

4. Arteta, C. Hale, G. (2008), "Sovereign debt crises and credit to the private sector," Journal of International Economics, 74, 53-69.

5. Blalock, G., P. Gertler, and D. Levine (2008) "Financial constraints on investment in an emerging market crisis," Journal of Monetary Economics, 55(3): 568-91.

6. Blundell, R. and S. Bond (1998) "Initial Conditions and Moment Restrictions in Dynamic Panel Data Models," Journal of Econometrics, 68: 29-51.

7. Bordo, M. A. Cavallo and C. Meissner (2010) "Sudden stops: Determinants and output effects in the first era of globalization, 1880-1913, "Journal of Development Economics, 91(2): 227-241.

8. Bordo, M. and M. Flandreau (2003) "Core, Periphery, Exchange Rate Regimes, and Globalization" in M. Bordo, A. Taylor and J. Williamson, eds. Globalization in Historical Perspective, Chicago: University of Chicago Press, pp. 417-72.

9. Bordo, M. and K. Oosterlinck (2005) "Do political changes trigger debt default? And do defaults lead to political changes?" Mimeo.

10. Broner, F. and J. Ventura (2010) "Rethinking the Effects of Financial Liberalization," NBER Working Paper \# 16640. 
11. Bulow, J. and K. Rogoff (1989) “Sovereign Debt: Is to Forgive to Forget?” American Economic Review, 79 (1): 43-50.

12. Catão, L. and S. Solomou (2005) "Effective Exchange Rates and the Classical Gold Standard Adjustment," American Economic Review, 95(4): 1259-75.

13. Cavallo, E. and P. Valenzuela (2010) "The Determinants of Corporate Risk in Emerging Markets: An Option-Adjusted Spread Analysis," International Journal of Finance and Economics, 15(1): 57-74.

14. Chabot, B. and C. Kurz (2010) "That's Where the Money Was: Foreign Bias and English Investment Abroad, 1866-1907,” Economic Journal, 120(547): 1056-79.

15. Clemens, M. and J. Williamson (2004) "Wealth Bias in the First Global Capital Market Boom, 1870-1913," Economic Journal 114: 303-37.

16. Cole, H. And P. Kehoe (1998) "Models of Sovereign Debt: Partial versus General Reputations," International Economic Review, 39: 55-70.

17. Cruces, J. and C. Trebesch (2013) "Sovereign Defaults: The Price of Haircuts," American Economic Journal: Macroeconomics 5(3): 85-117.

18. Das, U., M. Papaioannou and C. Trebesch (2010) "Sovereign Default Risk and Private Sector Access to Capital in Emerging Markets,” IMF Working Paper 10/10.

19. Dempster, A. P., N. M. Laird, and D. B. Rubin (1977) "Maximum likelihood from incomplete data via the EM algorithm," Journal Royal Statistical Society B, 39: 1-22.

20. Durbin, E. and D. Ng (2005) "The Sovereign Ceiling and Emerging Market Corporate Bond Spreads," Journal of International Money and Finance 24: 631-49.

21. Edelstein, M. (1982) Overseas investment in the age of high imperialism: the United Kingdom, 1850-1914, New York: Columbia University Press. 
22. Easterly, W. and S. Rebelo (1993) "Fiscal policy and economic growth," Journal of Monetary Economics, 32, 417-458.

23. Eichengreen, B., G. Hale and A. Mody (2001) "Flight to quality: investor risk tolerance and the spread of emerging market crises," in S. Claessens and K. Forbes (eds.), International Financial Contagion, Springer, pp. 129-156.

24. Eichengreen, B. and A. Mody (2000) "Lending Booms, Reserves, and the Sustainability of Short-Term Debt: Inferences from the Pricing of Syndicated Bank Loans," Journal of Development Economics, 63(1): 5-44.

25. Eichengreen, B. and R. Portes (1989) "Setting Defaults in the Era of Bond Finance," World Bank Economic Review 3(2): 211-39.

26. Eichengreen, B. and R. Portes (2000) "Debt Restructuring With and Without the IMF" in A. Meltzer, Financial Institutions Advisory Committee Expert Papers, Washington, DC: Government Printing Office.

27. Eichengreen, B. and C. Werley (1988) "How the Bondholders Fared: Realized Rates of Return on Foreign Dollar Bonds Floated in the 1920s," University of California at Berkeley, Economics Working Papers, no. 8869.

28. Esteves, R. (2011) "The Belle Époque of International Finance. French Capital Exports, 1880-1914," University of Oxford, Department of Economics Working Paper no. 534.

29. Ferguson, N. and M. Schularick (2012) "The "Thin Film of Gold": Monetary Rules and Policy Credibility” European Review of Economic History 16 (4): 384-407.

30. Flandreau, M. and F. Zumer (2004) Making of Global Finance, 1880-1913. Paris: OECD. 
31. Flores, J. (2010) “On Trade, Sovereign Defaults and Economics: New Evidence from the $19^{\text {th }}$ Century," Mimeo.

32. Flores, J. (2011) "Living with the Big Bad Wolf. Sovereign Risk and Economic Growth, 1870-1913," Mimeo.

33. Gelos, R., R. Sahay and G. Sandleris (2011) "Sovereign borrowing by developing countries: what determines market access," Journal of International Economics, 83(2): 243-54.

34. Grandes, M., D. Panigo and R. Pasquini (2010) "Corporate Credit Spreads and the Sovereign Ceiling in Latin America," Mimeo.

35. Guembel, A. and O. Sussman (2009) "Sovereign Debt Without Default Penalties," Review of Economic Studies, 76(4): 1297-1320

36. Hale, G. and C. Arteta (2009) "Currency Crises and Foreign Credit in Emerging Markets: Credit Crunch or Demand Effect?” European Economic Review 53(): 758-774.

37. Kalemli-Ozcan, S., H. Kamil, and C. Villegas-Sanchez (2010) "What Hinders Investment in the Aftermath of Financial Crises: Insolvent Firms or Illiquid Banks?" NBER Working Paper \#16528.

38. Kaminsky, G., S. Lizondo and C. Reinhart (1998) "Leading indicators of currency crises," IMF Staff Papers, 45, 1-48.

39. Kaminsky, G. and S. Schmukler (2002) "Emerging Market Instability: Do Sovereign Ratings Affect Country Risk and Stock Returns?" World Bank Economic Review, 16(2): $171-95$.

40. Leamer, E. (1983) "Let's take the con out of econometrics," American Economic Review, 73, 31-43. 
41. Le Bris, David (2013) "Why did French Savers buy Foreign Assets before 1914? A Methodological Approach to the Decomposition of the Benefits from Diversification," Louvain Economic Review 79(3): 71-89.

42. Levine, R. and D. Renelt (1992) “A sensitivity analysis of cross-country growth regressions," American Economic Review, 82, 943-63.

43. Lindert, P. and P. Morton (1989) "How Sovereign Debt Has Worked," in J. Sachs (ed.), Developing Country Debt and Economic Performance. Vol 1 The International Financial System, Chicago: Chicago University Press, pp. 39-106.

44. Little, R. and D. Rubin, D. (1987) "Statistical analysis with missing data," New York: John Wiley \& Sons.

45. Malik, A. and J. Temple (2009) "The geography of output volatility," Journal of Development Economics, 90(2): 163-178.

46. Mauro, P., N. Sussman and Y. Yafeh (2006) Emerging Markets and Financial Globalisation: Sovereign Bond Spreads in 1870-1913 and Today, Oxford: Oxford University Press.

47. Mitchener, K. and M. Weidenmier (2010) "Supersanctions and Sovereign Debt Repayment," Journal of International Money and Finance, 29 (1): 19-36.

48. Mody, A., M. Taylor and J. Kim (2001) "Modelling fundamentals for forecasting capital flows to emerging markets," International Journal of Finance and Economics, 6, 201-216.

49. Müller, Johannes (1988), Der deutsche Rentenmarkt vor dem Ersten Weltkrieg, eine Indexanalyse, Frankfurt/Main: Knapp.

50. O'Rourke, K. and J. Williamson (1999). Globalization and History. The Evolution of a Nineteenth-Century Atlantic Economy. Cambridge, Mass: MIT Press. 
51. Özler, S. (1993) "Have Commercial Banks Ignored History?" American Economic Review, 83(3): 608-620.

52. Raftery, A. (1995) "Bayesian Model selection in social research," Sociological Methodology 25: 111-63.

53. Reinhart, C. and K. Rogoff. (2004) "Serial Default and The 'Paradox' Of Risk-ToPoor Capital Flows," American Economic Review, 94(2): 53-58.

54. Reinhart, C. and K. Rogoff. (2009) This Time is Different. Eight Centuries of Financial Folly," Princeton: Princeton University Press.

55. Roodman, D. (2009) "A Note on the Theme of Too Many Instruments," Oxford Bulletin of Economics and Statistics, 71(1): 135-158

56. Rose, A. and M. Spiegel (2002) “A Gravity Model of Sovereign Lending: Trade, Default, and Credit," Federal Reserve Bank of San Francisco: Working Paper 2002-09.

57. Rousseeuw, P.J. and K. van Driessen (1999) "A fast algorithm for the minimum covariance determinant estimator," Technometrics, 41: 212-223.

58. Sala-i-Martin, X., G. Doppelhofer and R. Miller (2004) "Determinants of long-run growth: A Bayesian Averaging Classical Estimates (BACE) approach," American Economic Review, 94(4): 813-835.

59. Sandleris, G. (2012) "The Costs of Sovereign Defaults: Theory and Empirical Evidence" Universidad Torcuato di Tella, Documento de Trabajo 02/2012.

60. Sandleris, G. (2014) "Sovereign Defaults, Domestic Credit Market Institutions and Credit to the Private Sector," Journal of Money, Credit and Banking 46(2-3): 321-45.

61. Schaefer, Karl C. (1993), Deutsche Portfolioinvestitionen im Ausland 1870-1914. Banken, Kapitalmärkte und Wertpapierhandel im Zeitalter des Imperialismus, Münster: LIT 
62. Stone, I. (1999) The Global Export of Capital from Great Britain, 1865-1914. A Statistical Survey, London: Macmillan.

63. Sturzenegger, F. and J. Zettelmeyer (2006) Debt Defaults and Lessons from a Decade of Crises. Boston, Mass: MIT Press.

64. Tomz, M. (2007) Reputation and International Cooperation. Sovereign Debt Across Three Centuries, Princeton: Princeton University Press.

65. Trebesch, C. (2009) "The Cost of Aggressive Sovereign Debt Policies: How Much is the Private Sector Affected?" IMF Working Paper 09/29.

66. Uribe, M. and V. Yue (2006) "Country Spreads and Emerging Countries: Who Drives Whom?" Journal of International Economics, 69(1): 6-36.

67. Williamson, J. (2006) Globalization and the Poor Periphery Before 1950, Cambridge, Mass: MIT Press.

68. Wright, M. and M. Tomz (2007) “Do Countries Default in Bad Times?” Journal of the European Economic Association, 5(2-3):352-360. 
Table 1: Countries and Territories Included in Sample

\begin{tabular}{lccc}
\hline Name & Sovereign & Classification & Defaults \\
\hline \hline Argentina & $1880-1913$ & Emerging & $1890-93$ \\
Austria-Hungary & $1880-1913$ & Developed & \\
Brazil & $1880-1913$ & Emerging & 1898 \\
Chile & $1880-1913$ & Emerging & $1880-83$ \\
Colombia & $1880-1913$ & Emerging & $1880-96,1900-04$ \\
Denmark & $1880-1913$ & Developed & \\
Greece & $1880-1913$ & Emerging & $1894-97$ \\
Italy & $1880-1913$ & Emerging & \\
Japan & $1880-1913$ & Emerging & \\
Mexico & $1880-1913$ & Emerging & $1866-85$ \\
Norway & $1880-1913$ & Emerging & \\
Ottoman Empire & $1880-1913$ & Emerging & $1876-81$ \\
Peru & $1880-1913$ & Emerging & $1876-89$ \\
Portugal & $1880-1913$ & Emerging & $1892-1901$ \\
Russia & $1880-1913$ & Emerging & \\
Serbia & $1880-1913$ & Emerging & 1895 \\
Spain & $1880-1913$ & Emerging & \\
Sweden & $1880-1913$ & Emerging & \\
United States & $1880-1913$ & Emerging & \\
Uruguay & $1880-1913$ & Emerging & 1891 \\
Australia & $1901-1913$ & Emerging & \\
Canada & $1880-1913$ & Emerging & \\
New Zealand & $1907-1913$ & Emerging & \\
\hline
\end{tabular}


Table 2: Summary of Indices and Descriptive Statistics

\begin{tabular}{|c|c|c|c|c|}
\hline Concept & Acronyms & Average & $\begin{array}{l}\text { Standard } \\
\text { deviation }\end{array}$ & Variables \\
\hline International competitiveness & Ic1 & 0 & 1 & $\begin{array}{l}\text { exogenous terms-of-trade } \\
\text { total exports } \\
\text { total imports } \\
\text { tariffs }\end{array}$ \\
\hline $\begin{array}{l}\text { Investment climate and monetary } \\
\text { stability }\end{array}$ & Icms 1 & 0 & 1 & $\begin{array}{l}\text { debt service over exports } \\
\text { total exports per capita } \\
\text { inflation rate }\end{array}$ \\
\hline Financial development & gold & 0.5717 & 0.4951 & gold standard membership \\
\hline Long-run macroeconomic & Imp1 & 0 & 1 & arable land \\
\hline prospects & $\operatorname{Imp} 2$ & 0 & 1 & $\begin{array}{l}\text { econ. distance from } \\
\text { London } \\
\text { 5-year lag of net migration } \\
\text { index } \\
\text { population growth } \\
\text { schooling } \\
\text { urbanization rate }\end{array}$ \\
\hline Political stability & ps1 & 0 & 1 & $\begin{array}{l}\text { extrastate war } \\
\text { interstate war } \\
\text { interstate dispute } \\
\text { internal war }\end{array}$ \\
\hline Global supply of capital & $\begin{array}{l}\text { igbshortbank } \\
\text { igblong }\end{array}$ & $\begin{array}{l}3.3773 \\
2.7742 \\
\end{array}$ & $\begin{array}{l}0.6648 \\
0.2733 \\
\end{array}$ & $\begin{array}{l}3 \text { mos. bills rate in London } \\
\text { yields of British consols }\end{array}$ \\
\hline
\end{tabular}

Table 3: Factor Loadings and Uniqueness

\begin{tabular}{|c|c|c|c|c|c|c|}
\hline \multirow[t]{2}{*}{ Variables } & \multicolumn{5}{|c|}{ Factors } & \multirow[t]{2}{*}{ Uniqueness } \\
\hline & Ic1 & Icms1 & Imp1 & Imp2 & ps1 & \\
\hline exogenous terms-of-trade & 0.0987 & & & & & 0.9634 \\
\hline total exports & 0.9782 & & & & & 0.0430 \\
\hline total imports & 0.9817 & & & & & 0.0325 \\
\hline tariffs & -0.3125 & & & & & 0.8477 \\
\hline debt service over exports & & 0.6250 & & & & 0.6094 \\
\hline total exports per capita & & -0.6251 & & & & 0.6093 \\
\hline inflation rate & & 0.0057 & & & & 0.9997 \\
\hline arable land & & & 0.3249 & -0.0199 & & 0.8391 \\
\hline economic distance from London & & & 0.8257 & -0.1797 & & 0.2859 \\
\hline 5-year lag of net migration index & & & 0.8763 & 0.1870 & & 0.1863 \\
\hline population growth & & & 0.5952 & 0.2455 & & 0.5198 \\
\hline schooling & & & -0.2033 & 0.4893 & & 0.7175 \\
\hline urbanization rate & & & 0.3858 & 0.5164 & & 0.5739 \\
\hline extrastate war & & & & & 0.0304 & 0.9738 \\
\hline interstate war & & & & & 0.4945 & 0.7554 \\
\hline interstate dispute & & & & & 0.5119 & 0.7373 \\
\hline internal war & & & & & 0.2295 & 0.9304 \\
\hline$\%$ explained & 0.96 & 0.99 & 0.73 & 0.22 & 0.93 & \\
\hline
\end{tabular}


Table 4: Reduced-Form Estimates (Fixed Effects Models)

\begin{tabular}{|c|c|c|c|}
\hline Spec. & (1) & (2) & (3) \\
\hline & Total & Total & Great Britain \\
\hline Default year & $\begin{array}{c}-0.96 \\
(1.274)\end{array}$ & $\begin{array}{l}-1.022 \\
(1.874)\end{array}$ & $\begin{array}{c}0.239 \\
(1.826)\end{array}$ \\
\hline Default continued & $\begin{array}{l}-1.483 * * \\
(0.554)\end{array}$ & $\begin{array}{l}-1.015 \\
(0.638)\end{array}$ & $\begin{array}{c}0.050 \\
(0.801)\end{array}$ \\
\hline Rescheduling & $\begin{array}{l}-1.251^{* *} \\
(0.591)\end{array}$ & $\begin{array}{c}-1.062 \\
(0.891)\end{array}$ & $\begin{array}{c}-0.518 \\
(0.976)\end{array}$ \\
\hline Default length & $\begin{array}{r}1.637 \\
(1.139)\end{array}$ & $\begin{array}{r}2.353 \\
(1.495)\end{array}$ & $\begin{array}{c}1.146 \\
(1.439)\end{array}$ \\
\hline Memory & $\begin{array}{l}-0.935 * * * \\
(0.307)\end{array}$ & $\begin{array}{l}-0.947 * * \\
(0.418)\end{array}$ & $\begin{array}{l}-0.542 \\
(0.462)\end{array}$ \\
\hline Int'l competitiveness & & $\begin{array}{r}0.394 \\
(0.447)\end{array}$ & $\begin{array}{c}0.016 \\
(0.453)\end{array}$ \\
\hline Inv't climate/ monet stab. & & $\begin{array}{c}-0.057 \\
(0.080)\end{array}$ & $\begin{array}{l}-0.075 \\
(0.076)\end{array}$ \\
\hline Gold standard & & $\begin{array}{l}0.761 * * * \\
(0.262)\end{array}$ & $\begin{array}{l}0.854 * * \\
(0.336)\end{array}$ \\
\hline Macro fundamentals (1st) & & $\begin{array}{l}1.279 * * * \\
(0.236)\end{array}$ & $\begin{array}{l}1.324 * * * \\
(0.262)\end{array}$ \\
\hline Macro fundamentals (2nd) & & $\begin{array}{r}0.682 \\
(0.775)\end{array}$ & $\begin{array}{l}-0.181 \\
(0.894)^{-1}\end{array}$ \\
\hline Political stability & & $\begin{array}{c}-0.084 \\
(0.106)\end{array}$ & $\begin{array}{l}-0.116 \\
(0.090)^{-1}\end{array}$ \\
\hline UK short interest rate & & $\begin{array}{c}-0.001 \\
(0.280)\end{array}$ & $\begin{array}{l}-0.050 \\
(0.443)\end{array}$ \\
\hline UK long interest rate & & $\begin{array}{c}-0.621 \\
(0.580)\end{array}$ & $\begin{array}{l}-0.634 \\
(0.545)\end{array}$ \\
\hline Real exc rate & & $\begin{array}{l}0.000 \\
(0.001)\end{array}$ & $\begin{array}{l}0.001 \\
(0.001)\end{array}$ \\
\hline Currency crises & & $\begin{array}{c}-0.308 \\
(0.345)\end{array}$ & $\begin{array}{l}-0.200 \\
(0.289)\end{array}$ \\
\hline Banking crises & & $\begin{array}{r}0.140 \\
(0.259)\end{array}$ & $\begin{array}{l}-0.055 \\
(0.246)\end{array}$ \\
\hline Observations & 613 & 560 & 506 \\
\hline R-squared & 0.162 & 0.243 & 0.303 \\
\hline
\end{tabular}


Table 5: Estimates Accounting for Endogeneity

\begin{tabular}{|c|c|c|c|c|}
\hline $\begin{array}{l}\text { Spec. } \\
\text { Method } \\
\text { Equation }\end{array}$ & $\begin{array}{c}(1) \\
\text { GMM } \\
\text { Total }\end{array}$ & $\begin{array}{c}\text { (2) } \\
\text { GMM } \\
\text { Great Britain }\end{array}$ & $\begin{array}{c}\text { (3) } \\
\text { 3SLS } \\
\text { Demand }\end{array}$ & $\begin{array}{c}\text { (4) } \\
\text { 3SLS } \\
\text { Spreads }\end{array}$ \\
\hline Lagged dep. var. & $\begin{array}{c}0.261 * * \\
(0.115)\end{array}$ & $\begin{array}{c}0.299 * * * \\
(0.065)\end{array}$ & & \\
\hline Spreads & & & $\begin{array}{c}0.161 \\
(0.849)\end{array}$ & \\
\hline UK short interest rate & $\begin{array}{l}-0.046 \\
(0.082)\end{array}$ & $\begin{array}{l}-0.021 \\
(0.111)\end{array}$ & & $\begin{array}{c}0.398 \\
(0.387)\end{array}$ \\
\hline UK long interest rate & $\begin{array}{c}-0.183 \\
(0.213)\end{array}$ & $\begin{array}{c}0.153 \\
(0.296)\end{array}$ & & $\begin{array}{c}-0.698 \\
(0.659)\end{array}$ \\
\hline Default year & $\begin{array}{c}0.444 \\
(1.018)\end{array}$ & $\begin{array}{c}0.836 \\
(0.909)\end{array}$ & $\begin{array}{c}-2.661 \\
(11.499)\end{array}$ & $\begin{array}{c}13.236^{* * * *} \\
(1.554)\end{array}$ \\
\hline Default continued & $\begin{array}{c}-1.392 * * \\
(0.575)\end{array}$ & $\begin{array}{c}-0.567 \\
(0.654)\end{array}$ & $\begin{array}{c}-2.584 \\
(11.525)\end{array}$ & $\begin{array}{c}13.565 * * * \\
(0.727)\end{array}$ \\
\hline Rescheduling & $\begin{array}{c}-0.973 * * \\
(0.463)\end{array}$ & $\begin{array}{l}-0.712 \\
(0.733)\end{array}$ & $\begin{array}{l}-2.598 \\
(8.920)\end{array}$ & $\begin{array}{c}10.496 * * * \\
(0.796)\end{array}$ \\
\hline Default length & $\begin{array}{c}1.983 * * * \\
(0.671)\end{array}$ & $\begin{array}{c}0.938 \\
(0.805)\end{array}$ & $\begin{array}{c}3.341 \\
(10.376)\end{array}$ & $\begin{array}{c}-12.112 * * * \\
(1.128)\end{array}$ \\
\hline Memory & $\begin{array}{c}-1.254 * * * \\
(0.477)\end{array}$ & $\begin{array}{l}-0.461 \\
(0.611)\end{array}$ & $\begin{array}{c}-0.971 \\
(1.190)\end{array}$ & $\begin{array}{c}1.336 * * * \\
(0.367)\end{array}$ \\
\hline Int'l competitiveness & $\begin{array}{c}0.715^{* * * *} \\
(0.228)\end{array}$ & $\begin{array}{c}0.44 \\
(0.284)\end{array}$ & $\begin{array}{c}1.181 * \\
(0.640)\end{array}$ & $\begin{array}{c}-0.741 * * * \\
(0.096)\end{array}$ \\
\hline Inv't climate/ monet stab. & $\begin{array}{c}-0.127 \\
(0.166)\end{array}$ & $\begin{array}{c}-0.034 \\
(0.257)\end{array}$ & $\begin{array}{c}-0.144 \\
(0.154)\end{array}$ & $\begin{array}{l}-0.143 * \\
(0.081)\end{array}$ \\
\hline Gold standard & $\begin{array}{c}0.187 \\
(0.286)\end{array}$ & $\begin{array}{l}-0.415 \\
(0.399)\end{array}$ & $\begin{array}{c}0.112 \\
(0.622)\end{array}$ & $\begin{array}{c}-0.702 * * * \\
(0.148)\end{array}$ \\
\hline Macro fundamentals (1st) & $\begin{array}{c}0.427 * * \\
(0.206)\end{array}$ & $\begin{array}{c}0.626 * * * \\
(0.149)\end{array}$ & $\begin{array}{c}0.790 * * * \\
(0.070)\end{array}$ & $\begin{array}{c}0.033 \\
(0.061)\end{array}$ \\
\hline Macro fundamentals (2nd) & $\begin{array}{c}0.519 * * * \\
(0.193)\end{array}$ & $\begin{array}{l}-0.055 \\
(0.264)\end{array}$ & $\begin{array}{l}0.312 * \\
(0.187)\end{array}$ & $\begin{array}{l}0.188 * \\
(0.096)\end{array}$ \\
\hline Political stability & $\begin{array}{c}-0.157 * * \\
(0.069)\end{array}$ & $\begin{array}{c}0.001 \\
(0.002)\end{array}$ & $\begin{array}{c}0.016 \\
(0.079)\end{array}$ & $\begin{array}{c}0.049 \\
(0.068)\end{array}$ \\
\hline Real exc. rate & $\begin{array}{c}0.001 \\
(0.001)\end{array}$ & $\begin{array}{c}-0.946 * \\
(0.540)\end{array}$ & $\begin{array}{c}0.003 \\
(0.002)\end{array}$ & $\begin{array}{c}-0.002^{* *} \\
(0.001)\end{array}$ \\
\hline Currency crises & $\begin{array}{c}-1.222 * \\
(0.639)\end{array}$ & $\begin{array}{c}0.214 \\
(0.464)\end{array}$ & $\begin{array}{c}0.331 \\
(0.617)\end{array}$ & $\begin{array}{c}-0.577 \\
(0.351)\end{array}$ \\
\hline Banking crises & $\begin{array}{l}-0.296 \\
(0.493)\end{array}$ & $\begin{array}{c}0.001 \\
(0.002)\end{array}$ & $\begin{array}{c}0.428 \\
(0.318)\end{array}$ & $\begin{array}{c}0.153 \\
(0.266)\end{array}$ \\
\hline $\begin{array}{l}\text { Observations } \\
\text { R-squared }\end{array}$ & 515 & 447 & $\begin{array}{c}545 \\
0.450\end{array}$ & $\begin{array}{c}545 \\
0.731\end{array}$ \\
\hline Hansen (p-value) & 1 & 1 & & \\
\hline AR(1) (p-value) & 0 & 0 & & \\
\hline $\operatorname{AR}(2)(p$-value $)$ & 0.188 & 0.566 & & \\
\hline
\end{tabular}

Note: The dependent variable is the log of the capital flows from Great Britain, France and Germany, deflated by the UK price index. Estimation is by system GMM (cols. 1-2) or 3SLS (cols. 3-4). Robust heteroskedastic-consistent standard errors are in parenthesis. The Hansen test evaluates the validity of the instrument set, i.e., tests for over-identifying restrictions. AR(1) and AR(2) are the Arellano-Bond autocorrelation tests of first and second order (the null is no autocorrelation), respectively. For the supply equations the dependent variable is the spread of long-term government bonds over British consols (in percentage points). A constant term has been estimated but is omitted for parsimony. $*, * *, * * *$ denote significance at 10,5 and $1 \%$ levels. 
Table 6: Extreme Bounds Analysis

\begin{tabular}{c|cccc}
\hline Capital flows measure & \multicolumn{2}{|c}{ Total } & \multicolumn{2}{c}{ Great Britain } \\
\hline Variables & Lower bound & Upper bound & Lower bound & Upper bound \\
\hline Sovereign default & $-2.387^{* * *}$ & $-0.7326^{* *}$ & $-1.7438^{* * * *}$ & $1.2421^{* *}$ \\
& $(-5.000)$ & $(-2.090)$ & $(-5.218)$ & $(2.370)$ \\
\hline \multicolumn{2}{l}{ Note: t-ratios in parenthesis. ${ }^{*}, * *, * * *$} & denote significance levels at 10,5 and $1 \%$, \\
respectively.
\end{tabular}

Table 7: Top BMA-type Models

\begin{tabular}{l|cc}
\hline \multicolumn{1}{c|}{ Dep. Var. } & $\mathbf{1}$ & $\mathbf{2}$ \\
\hline default & Total & Great Britain \\
exogenous terms-of-trade & $*$ & $*$ \\
total exports & & \\
total imports & & \\
tariffs & $*$ & \\
arable land & $*, \mathrm{~s}$ & $*, \mathrm{~s}$ \\
economic distance from London & $*, \mathrm{~s}$ & $*$ \\
5-year lag of net migration index & $*$ & $*$ \\
population growth & $*, \mathrm{~s}$ & $*$ \\
schooling & $*, \mathrm{~s}$ & $*, \mathrm{~s}$ \\
urbanization rate & & \\
R-squared & 0.26 & 0.37 \\
\hline
\end{tabular}

Note: This table presents the top models for the total level of real capital flows and its disaggregation by country of origin. The variables' description is in the main text. * and $\mathrm{s}$, denote inclusion of the variable in the BMA regression and whether it reported a statistically significant coefficient at a $10 \%$ level or lower, respectively. 
Table 8: 3SLS Estimates by Sector

\begin{tabular}{|c|c|c|c|c|}
\hline \multirow{3}{*}{$\begin{array}{l}\text { Sector } \\
\text { Spec. } \\
\text { Equation }\end{array}$} & \multicolumn{2}{|c|}{ Exportables } & \multicolumn{2}{|c|}{ Non exportables } \\
\hline & (1) & (2) & (3) & (4) \\
\hline & Demand & Spreads & Demand & Spreads \\
\hline Spreads & 0.104 & & $-0.514 *$ & \\
\hline & $(0.175)$ & & $(0.296)$ & \\
\hline UK short interest rate & & $\begin{array}{c}-1.290 * * * \\
(0.433)\end{array}$ & & $\begin{array}{c}0.029 \\
(0.424)\end{array}$ \\
\hline UK long interest rate & & $\begin{array}{c}2.728 * * * \\
(0.665)\end{array}$ & & $\begin{array}{c}0.553 \\
(0.640)\end{array}$ \\
\hline Default year & & $\begin{array}{c}12.965 * * * \\
(1.659)\end{array}$ & & $\begin{array}{c}7.240 * * * * \\
(1.540)\end{array}$ \\
\hline Default continued & $\begin{array}{l}-1.167 \\
(1.296)\end{array}$ & $\begin{array}{c}10.430 * * * \\
(1.045)\end{array}$ & $\begin{array}{l}-0.342 \\
(1.444)\end{array}$ & $\begin{array}{c}7.905 * * * \\
(0.869)\end{array}$ \\
\hline Rescheduling & $\begin{array}{l}-0.138 \\
(1.251)\end{array}$ & $\begin{array}{c}8.486 * * * \\
(0.962)\end{array}$ & $\begin{array}{c}1.108 \\
(2.121)\end{array}$ & $\begin{array}{c}7.569 * * * \\
(0.971)\end{array}$ \\
\hline Default length & $\begin{array}{c}0.205 \\
(1.086)\end{array}$ & $\begin{array}{c}-11.907 * * * \\
(1.461)\end{array}$ & $\begin{array}{c}2.134 \\
(1.519)\end{array}$ & $\begin{array}{c}-6.257^{* * * *} \\
(1.250)\end{array}$ \\
\hline Memory & $\begin{array}{l}-0.804 \\
(0.651)\end{array}$ & $\begin{array}{c}1.922 * * * \\
(0.402)\end{array}$ & $\begin{array}{l}-0.662 \\
(0.615)\end{array}$ & $\begin{array}{c}1.693 * * * \\
(0.348)\end{array}$ \\
\hline Int'l competitiveness & $\begin{array}{c}1.011 * * * \\
(0.181)\end{array}$ & $\begin{array}{c}-0.282^{* * *} \\
(0.129)\end{array}$ & $\begin{array}{c}0.555 * * * \\
(0.175)\end{array}$ & $\begin{array}{c}-0.494 * * * \\
(0.115)\end{array}$ \\
\hline Inv't climate/ monet stab. & $\begin{array}{c}-0.972 * * * \\
(0.169)\end{array}$ & $\begin{array}{c}0.059 \\
(0.125)\end{array}$ & $\begin{array}{c}-0.732 * * * \\
(0.156)\end{array}$ & $\begin{array}{l}-0.015 \\
(0.115)\end{array}$ \\
\hline Gold standard & $\begin{array}{l}-0.052 \\
(0.257)\end{array}$ & $\begin{array}{c}-0.700 * * * \\
(0.157)\end{array}$ & $\begin{array}{l}-0.254 \\
(0.229)\end{array}$ & $\begin{array}{c}-0.656^{* * * *} \\
(0.143)\end{array}$ \\
\hline Macro fundamentals (1st) & $\begin{array}{c}0.311 * * * \\
(0.094)\end{array}$ & $\begin{array}{c}-0.156^{* *} \\
(0.066)\end{array}$ & $\begin{array}{c}0.833 * * * \\
(0.085)\end{array}$ & $\begin{array}{l}-0.004 \\
(0.063)\end{array}$ \\
\hline Macro fundamentals (2nd) & $\begin{array}{c}0.017 \\
(0.156)\end{array}$ & $\begin{array}{l}0.197 * \\
(0.112)\end{array}$ & $\begin{array}{c}0.056 \\
(0.142)\end{array}$ & $\begin{array}{c}0.092 \\
(0.105)\end{array}$ \\
\hline Political stability & $\begin{array}{l}-0.081 \\
(0.089)\end{array}$ & $\begin{array}{l}-0.012 \\
(0.065)\end{array}$ & $\begin{array}{l}-0.077 \\
(0.082)\end{array}$ & $\begin{array}{l}-0.007 \\
(0.061)\end{array}$ \\
\hline Real exc rate & $\begin{array}{c}0.002 \\
(0.006)\end{array}$ & $\begin{array}{c}0.003 \\
(0.004)\end{array}$ & $\begin{array}{l}-0.003 \\
(0.005)\end{array}$ & $\begin{array}{c}0.001 \\
(0.003)\end{array}$ \\
\hline Currency crises & $\begin{array}{c}0.379 \\
(0.458)\end{array}$ & $\begin{array}{l}-0.443 \\
(0.340)\end{array}$ & $\begin{array}{c}0.185 \\
(0.452)\end{array}$ & $\begin{array}{c}-0.657 * * \\
(0.321)\end{array}$ \\
\hline Banking crises & $\begin{array}{l}-0.178 \\
(0.339)\end{array}$ & $\begin{array}{c}0.389 \\
(0.239)\end{array}$ & $\begin{array}{l}0.763 * * \\
(0.332)\end{array}$ & $\begin{array}{c}0.331 \\
(0.243)\end{array}$ \\
\hline Observations & 317 & 317 & 399 & 399 \\
\hline R-squared & 0.367 & 0.641 & 0.332 & 0.608 \\
\hline
\end{tabular}

Note: The dependent variable is the log of the capital flows from Great Britain, France and Germany, deflated by the UK price index. For the supply equations the dependent variable is the spread of long-term government bonds over British consols (in percentage points). Estimation is by three-stage least squares (3SLS). A constant term has been estimated but is omitted for parsimony. *, **, *** denote significance at 10,5 and $1 \%$ levels. 
Figure 1: Summary of Estimates of the Impact of Defaults on Capital Inflows

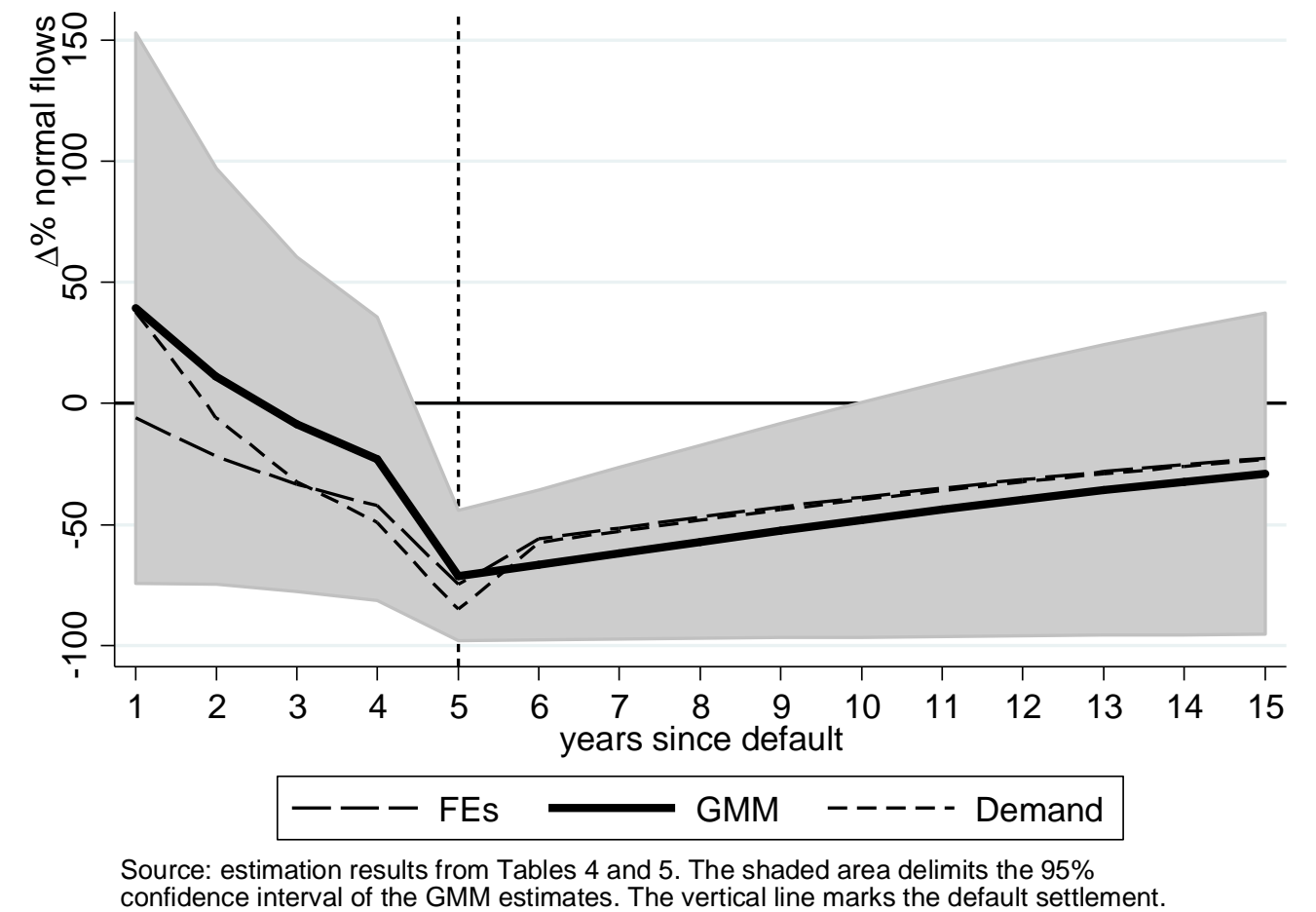

Figure 2: Conditional Mean Effect Size for Sovereign Default Coefficient

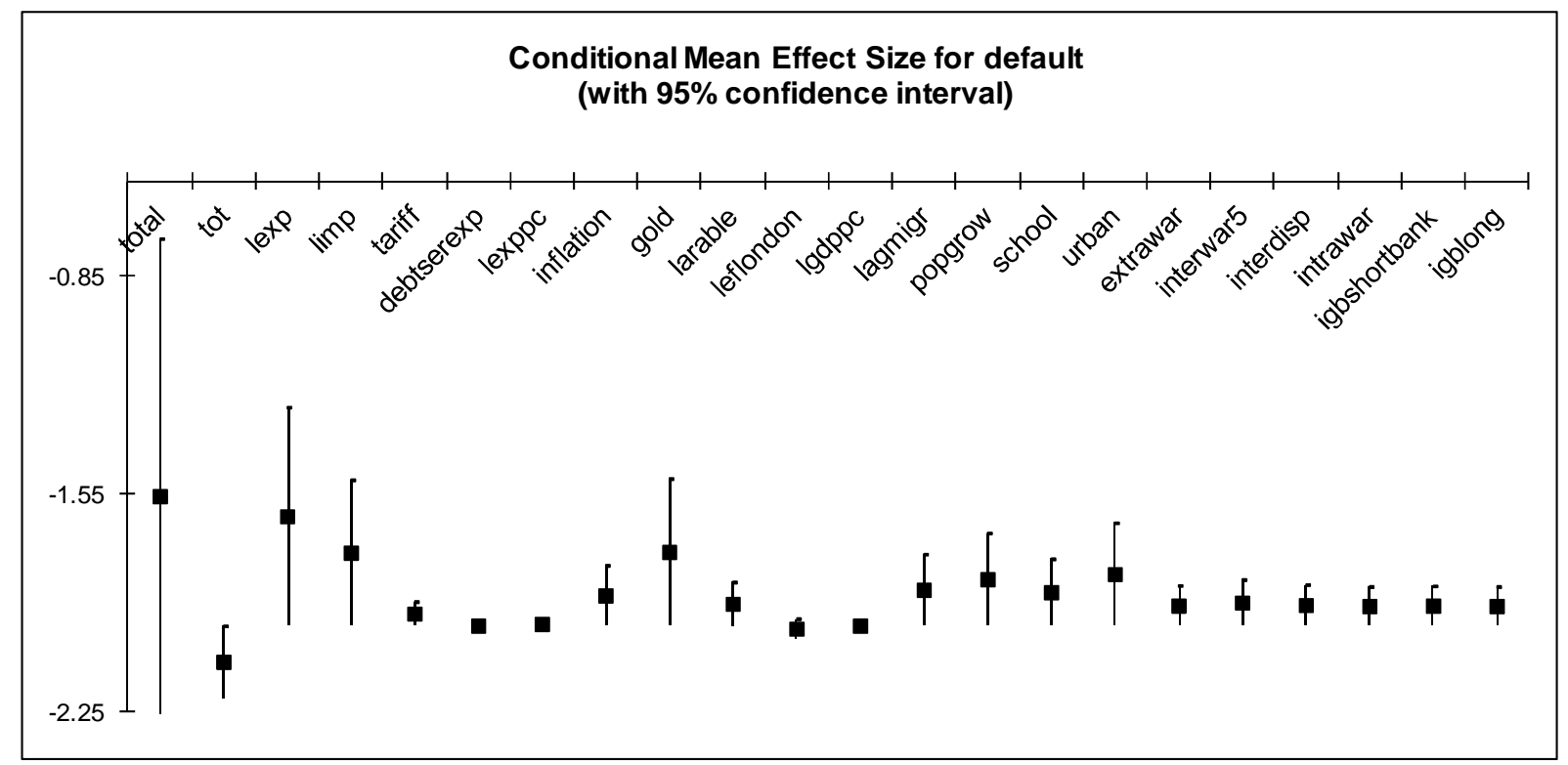

Note: authors' calculations.

\footnotetext{
${ }^{1}$ The latter is mechanic since he uses a finite game.

${ }^{2}$ This classification also takes into consideration the distance from the industrial core of Europe, reliance on capital inflows and relatively undeveloped capital markets (Mauro, Sussman and Yafeh 2006).
} 
${ }^{3}$ We regressed private capital inflows into time dummies for 3 years prior, 5 years during, and 3 years after a default episode. The regressions also included country fixed effects. We capped the length of defaults at 5 years because that is the median length of defaults in our sample.

${ }^{4}$ This difference is strongly significant with a one-sided Wald test statistic of 2.4.

${ }^{5}$ Wald statistic of 2.2 (one-sided).

${ }^{6}$ This variable captures the length of each separate default, i.e. we only count the length of default until the rescheduling year $r_{i t}$. The decay parameter $\theta_{1}$ is estimated in the literature through a preliminary grid search that converged to a value of 0.14 in our case. Related studies on sovereign spreads have documented a very similar value of 0.1, implying a fairly long memory effect (Eichengreen and Portes 2000, Flandreau and Zumer 2004).

${ }^{7}$ We depart here from Arteta and Hale (2008), who only estimated a constant effect in time of a default similar to the three first dummies in (1): $d_{i t}^{s}, n_{i t}$ and $r_{i t}$.

${ }^{8}$ Similarly to the length variable, in case of more than one default by the same country, we only count the memory between defaults, i.e. we count $t-r_{i t}$ up to the year before another default occurs.

${ }^{9}$ The grid search for this parameter converged to a value of 0.13 .

${ }^{10}$ A likelihood ratio (LR) test was used to examine the "sphericity" case, allowing for sampling variability in the correlations. This test comfortably rejects sphericity at the $1 \%$ level. The first factor explains $96 \%$ of the variance in the standardized data (see Table 2).

${ }^{11}$ Also in this case, the LR test comfortably rejects sphericity at the $1 \%$ level.

${ }^{12}$ Restricting the sample to countries for which we have information on the size of the banking sector (measured by deposits) does not change the results appreciably.

${ }^{13}$ This LR test still comfortably rejects sphericity at the $1 \%$ level.

${ }^{14}$ The LR test comfortably rejects sphericity at the $1 \%$ level.

${ }^{15}$ Because these variables do not vary across countries, they act as time fixed effects and so regressions that include them do not have year dummies.

${ }^{16}$ For a more specific treatment of endogeneity see the next sub-section.

${ }^{17}$ The correlation coefficient between ic1 and the MCD-equivalent (hereafter MDCeq) equals 99; the correlation coefficient between icms1 and the MCDeq equals $83 \%$; finally, the correlation coefficient(s) between $1 \mathrm{mp} 1$ (lmp2) and the MCDeq equals 36\% (89\%). All of these are statistically significant at the $1 \%$ level.

${ }^{18}$ Missing data also increases the degree of uncertainty and influences the ability to draw accurate conclusions. Indeed, PCA is based on an initial reduction of the data to the sample mean vector and sample covariance matrix of the variables, and this cannot be estimated from datasets with a large proportion of missing values (Little and Rubin 1987).

${ }^{19}$ We chose to use the varimax rotation method, which is an orthogonal rotation of the factor axes to maximize the variance of the squared loadings of a factor on all variables in a factor matrix.

${ }^{20}$ The EMA assumes that the data are missing at random (MAR) and in order to check that the MAR assumption can be applied to the variables under consideration, a test analysis called "separate variance t-test", in which rows are all variables which have $1 \%$ missing or more, and columns are all variables, is carried out. The p-values are more than 5\% meaning that missing cases in the row variable are not significantly correlated with the column variable, and this can be considered as MAR.

${ }^{21}$ To construct the index of international competitiveness we imputed $1.8 \%$ of the values of exports and $2.1 \%$ of imports. For the investment climate/ monetary stability index, we imputed $1.2 \%$ of the observations on the debt service and $4.6 \%$ of those on inflation.

${ }^{22}$ Uniqueness of a variable is the share of its variance that is not accounted by all the factors.

${ }^{23}$ This interpretation is also consistent with the negative sign of the factor loading of exports per capita.

${ }^{24}$ The stronger drivers of ps1 seem to be international wars (interstate5) and diplomatic disputes (interdisp), compared with civil wars and colonial conflicts.

${ }^{25} \mathrm{High}$ uniqueness in the case of land is probably due to the infrequent changes in this variable, associated with border alterations between countries.

${ }^{26}$ The fact that foreign capital was invested in the land- and resource-intensive sector of these nations is well documented in the historical literature (Stone 1999, Clemens and Williamson 2004, Esteves 2011). But another stylized fact of foreign investment in these nations is the growing importance of the urban sector (especially since the last decades of the $19^{\text {th }}$ century), namely for the buildup of public utilities and urban transportation.

${ }^{27}$ Moreover, the relation between sovereign and corporate yields can reverse during a sovereign crisis, as some private companies in Eurozone countries (Greece and Portugal) now enjoy better credit than their respective governments.

${ }_{28}$ This result confirms the conclusion of Clemens and Williamson (2004) that long-run macro fundamentals were the main drivers of international capital flows in the period.

${ }^{29}$ Bordo, Cavallo and Meissner (2010) found a similar result for a panel of nations in the same period as ours. 


\footnotetext{
${ }^{30}$ Nevertheless, Wright and Tomz (2007) found a negative but surprisingly weak correlation between domestic output and defaults over the period 1820-2004.

${ }^{31}$ Likewise, Bordo and Oosterlinck (2005) find some evidence that not only did political disturbances increase the likelihood of defaults but that governments were also punished politically after a default.

${ }^{32}$ We equally tried estimating (1) with a difference GMM estimator but decided against it because the lagged dependent variable was not significant. Moreover, the tenor of the results is very similar to the system GMM.

${ }^{33}$ Unlike priv $_{i t}$, the dependent variable in this equation $s_{i t}$ is measured in levels (percentage points), rather than logs.

${ }^{34}$ For Britain there are the Edelstein (1982) and Chabot and Kurz (2010) indices, whereas for France Esteves (2011) and Le Bris (2013) provide similar indices. Finally, on the returns of German private investments abroad see Müller (1988) and Schaefer (1993).

${ }^{35}$ Indeed, with 23 countries, 34 years, and a minimum of two sectors (exporting and non-exporting), we would need close to 1600 observations, each obtained from market indices of representative samples of individual securities. Moreover, many securities were not even listed in the main financial markets of the time, making their pricing even harder.

${ }^{36}$ Hence, positive coefficients reduce the supply of foreign funds (by increasing their cost).

${ }^{37}$ In other words, the raw coefficients are multiples of the standardized coefficients. If $\beta$ is the raw estimate of the effect of $x$ on $y$, the standardized coefficient is given by $\beta \times \sigma_{\mathrm{x}} / \sigma_{\mathrm{y}}=\beta / \sigma_{\mathrm{y}}$ in this case.

${ }^{38}$ Because of the non-linearity of equation (1), we estimated the confidence intervals using the so-called 'Delta method.'

${ }^{39}$ For posterior inclusion probabilities greater than 0.50 , this method provides a sign certainty index, which indicates whether the relationship between the left-hand-side variable and each of the independent variables is positive or negative. For concision we do not report these results here, but they are available from the authors on request.

${ }^{40}$ Tables with results available upon request.

${ }^{41}$ In particular, we excluded country-specific time dummies from the instrument set.

${ }^{42} \mathrm{We}$ cannot estimate the immediate impact of defaults in these models as the dummy for default years drops out on account of colinearity with the variable spreads.
} 